\title{
Is Neutrophil-Lymphocyte Count Ratio a Better Indicator of Sepsis with Gram-positive Bacterial Infection?
}

\author{
Uun Sumardi ${ }^{1} \odot$, Diah R Prihardianti ${ }^{2}$, Primal Sudjana $^{3} \odot$
}

\begin{abstract}
Background: Sepsis is the main cause of death in infectious diseases that can be caused by gram-negative or gram-positive bacteria. Definitive therapy for sepsis is antibiotics, depending on blood culture results even though it takes time for bacterial growth. Neutrophil-lymphocyte count ratio (NLCR) is a laboratory parameter that can predict bacterial infection in sepsis patients. NLCR is time-and-cost-effective and easyto-use in daily practice, in sepsis patients infected with gram-negative, gram-positive, and no bacterial growth based on blood culture results. Materials and methods: This was a comparative study of NLCR and the result of blood culture from sepsis patients. Subjects were obtained from the medical records of patients admitted to our hospital from January 2019 to May 2019. Patients aged over 18 years who were diagnosed with sepsis and had blood culture information were included. Patients with hematological disorder and malignancy were excluded. Sepsis data consisted of gender, age, source of infection, comorbidity, NLCR, and blood culture results.

Results: Ninety-four sepsis subjects met the inclusion criteria, and fifty-one subjects $(54.25 \%)$ - 33 subjects (35.10\%) with gram-negative bacterial infection and 18 subjects (19.15\%) with gram-positive bacterial infection-were included in the analysis due to the completeness of the data. The median NLCR (IQR) was 17.8 (14.3-30.7) in gram-negative, 31.5 (26.3-95.0) in gram-positive, and 22.8 (15.67-22.75) in no bacterial growth $(p=0.001)$.

Conclusion: NLCR can distinguish gram-negative and gram-positive bacterial infections. It also can predict the possibility of pathogenic bacteria that cause sepsis.

Keywords: Blood culture result, Neutrophil-lymphocyte count ratio (NLCR), Sepsis.

Indian Journal of Critical Care Medicine (2021): 10.5005/jp-journals-10071-23892
\end{abstract}

\section{INTRODUCTION}

Sepsis due to bacterial infection is one of the causes of high morbidity and mortality, especially in developing countries. ${ }^{1}$ The morbidity and mortality rate of sepsis and septic shock is $85 \%$, so it becomes a health problem. ${ }^{2}$ One of the causes of sepsis is gramnegative bacteria, and many of them are already resistant. In our tertiary referral hospital, in 2016, at the emergency room, 26.7\% of gram-negative bacteria produced extended-spectrum betalactamase (ESBL). Meanwhile, in the wards, $10.5 \%$ of ESBLEscherichia coli were found and in the ICU was $78.6 \%{ }^{3}$

Neutrophil-lymphocyte count ratio (NLCR) was obtained from absolute neutrophil (immature granules, rods, and segments) and absolute lymphocyte values based on the number of leukocytes. ${ }^{4}$ The clinicians need a laboratory test that is faster, easier, and cheaper and can be done in every hospital. NLCR value is a bacteremia marker that has a good diagnostic value for predicting bacteremia. No studies have looked at NLCR on gram-negative and gram-positive bacteria and no bacterial growth from blood cultures in sepsis patients.

\section{Materials and Methods}

This was a comparative study on NLCR and blood culture results from sepsis patients. Sepsis-3 criteria determined sepsis in the current study. ${ }^{5}$ Subjects were obtained from medical records of patients with a diagnosis of sepsis who were treated at our hospital, from January to May 2019. This study had received approval from the Health Research Ethics Committee of the hospital, with reference number LB.02.01/X.6.5/247/2019.

\footnotetext{
1,3Division of Tropical Medicine and Infectious Diseases, Department of Internal Medicine, Faculty of Medicine, Universitas Padjadjaran/Dr. Hasan Sadikin General Hospital, Bandung, West Java, Indonesia

${ }^{2}$ Department of Internal Medicine, Faculty of Medicine, Universitas Padjadjaran/Dr. Hasan Sadikin General Hospital, Bandung, West Java, Indonesia
}

Corresponding Author: Uun Sumardi, Division of Tropical Medicine and Infectious Diseases, Department of Internal Medicine, Faculty of Medicine, Universitas Padjadjaran/Dr. Hasan Sadikin General Hospital, Bandung, West Java, Indonesia, Phone: +62 817-0180-081, e-mail: uun_s_sppd@yahoo.co.id

How to cite this article: Sumardi U, Prihardianti DR, Sudjana P. Is Neutrophil-Lymphocyte Count Ratio a Better Indicator of Sepsis with Gram-positive Bacterial Infection? Indian J Crit Care Med 2021;25(7):795-799.

Source of support: Nil

Conflict of interest: None

Patients aged over 18 years who were diagnosed with the first episode of sepsis and had blood culture information were included. Patients with hematological disorder, malignancy, and corticosteroid medications were excluded. Sepsis subject data consisted of gender, age, source of infection, comorbidity, NLCR, and blood culture results. Statistical Package for Social Science (version 23) for Windows was used for data analysis. Statistical significance was set at $\leq 0.05$ with a two-tailed hypothesis. One-way analysis of variance test was used for normally distributed data;

(0) Jaypee Brothers Medical Publishers. 2021 Open Access This article is distributed under the terms of the Creative Commons Attribution 4.0 International License (https://creativecommons.org/licenses/by-nc/4.0/), which permits unrestricted use, distribution, and non-commercial reproduction in any medium, provided you give appropriate credit to the original author(s) and the source, provide a link to the Creative Commons license, and indicate if changes were made. The Creative Commons Public Domain Dedication waiver (http://creativecommons.org/publicdomain/zero/1.0/) applies to the data made available in this article, unless otherwise stated. 
otherwise, the Kruskal-Wallis test was used. The chi-square test was used for categorical data.

\section{Results}

There were 94 subjects diagnosed with a new-onset communityacquired sepsis, and 51 (54.25\%) positive cultures met the inclusion criteria, in which 33 (35.10\%) were gram-negative bacterial cultures and $18(19.15 \%)$ were gram-positive bacterial cultures. Blood culture results for gram-negative bacilli fermenter groups were $E$. coli $(n=11)$, Klebsiella pneumoniae $(n=5)$, Burkholderia cepacia $(n=2)$, Serratia marcescens $(n=2)$, and Salmonella typhi $(n=1)$. Blood culture results for gram-negative bacilli nonfermenter groups were Acinetobacter baumannii $(n=10)$ and Pseudomonas aeruginosa $(n=2)$. Blood culture results for gram-positive bacteria were Staphylococcus aureus $(n=9)$, Staphylococcus epidermidis ( $n=3$ ), Staphylococcus haemolyticus $(n=2)$, Staphylococcus hominis $(n=1)$, Streptococcus viridians $(n=2)$, and Enterococcus faecalis $(n=1)$.

Overall, NLCR for subjects with gram-positive bacteria was 31.5 (26.3-95.0) and subjects with gram-negative bacteria was 17.8 (14.3-30.7). The NLCR was lower in patients infected with gramnegative bacilli nonfermenter compared to those infected with gram-negative bacilli fermenter groups (Fig. 1). The median (IQR) of NLCR was significantly higher in female patients aged younger than 65 years, having chronic kidney disease (CKD), and with respiratory infections. Subject characteristics based on NLCR value and blood culture results are shown in Table 1.

Leukocytes, absolute neutrophils, absolute lymphocytes, and NLCR based on blood culture results are shown in Table 2. The median (IQR) of absolute lymphocyte count in patients infected with gram-positive bacteria was significantly lower at $360\left(239-742 / \mathrm{mm}^{3}\right)$ versus $712\left(573-1,138 / \mathrm{mm}^{3}\right)$ in those infected with gram-negative bacteria. The median absolute neutrophil count was higher in grampositive bacterial infection at 19,380 $\left(11,409-24,080 \mathrm{~mm}^{3}\right)$ versus gram-negative bacterial infection at 13,746 $\left(10,102-20,394 \mathrm{~mm}^{3}\right)$. The median leukocyte was higher in gram-positive bacterial infection at $21,375\left(12,410-26,098 \mathrm{~mm}^{3}\right)$ versus gram-negative bacterial infection at $15,620(11,425-22,835)$.
The Scattered-dot diagram shows that the gram-positive bacteria were MRSA (S. aureus), MRSCoN (S. epidermidis, $S$. haemolyticus, S. hominis), S. viridans (median NLCR of 95), and E. faecalis. The scattered-dot diagram showed the NLCR distribution of pathogenic bacteria of gram-negative grouped by fermenter and nonfermenter bacilli. The fermenter gram-negative bacilli (E. coli, K. pneumoniae, S. typhi, and S. marcescens) had a median NLCR in the red line of 19. The nonfermenter gram-negative bacilli (A. baumannii, P. aeruginosa, and Burkholderia cepacia) median NLCR was 22.

The distribution of the scattered-dot of no bacterial growth on blood culture results in a median NLCR was 22.8. It is lower than that in the gram-positive Table 3 and 4.

\section{Discussion}

We found that NLCR in subjects with gram-positive infection was higher than those with gram-negative infection. Similar to our study, Jonathan et al. reported that NLCR was significantly higher in gram-positive bacteria than in gram-negative bacteria $(p<0.05){ }^{6}$

Another report by Nurdani et al. showed that the ratio of neutrophil-lymphocytes in gram-positive bacteria was higher compared to gram-negative bacteria. ${ }^{7}$

Higher NLCR was found most prominently in female patients aged younger than 65 years, , having CKD, and with respiratory tract infection. This result was similar to a study conducted by Kim et al., which found that the mean age of the patients with gram-positive bacteria was $57 \pm 20$ years. ${ }^{6}$ Yana et al. also reported the mean age of sepsis subjects with bacterial growth in blood culture results was 53 years. ${ }^{8}$ Lower NLCR among the elderly may happen because the immune system becomes less effective at fighting infections.

Jonathan et al. also showed that female patients with Grampositive infection have higher NLCR. ${ }^{8}$ Female sex hormones exhibit protective effects that can contribute to the natural benefits of the septic condition. In comparison to this, postmenopausal women lack the benefits of this condition. ${ }^{9}$

There was no significant difference of NLCR value between grampositive and gram-negative in most comorbidity characteristics of

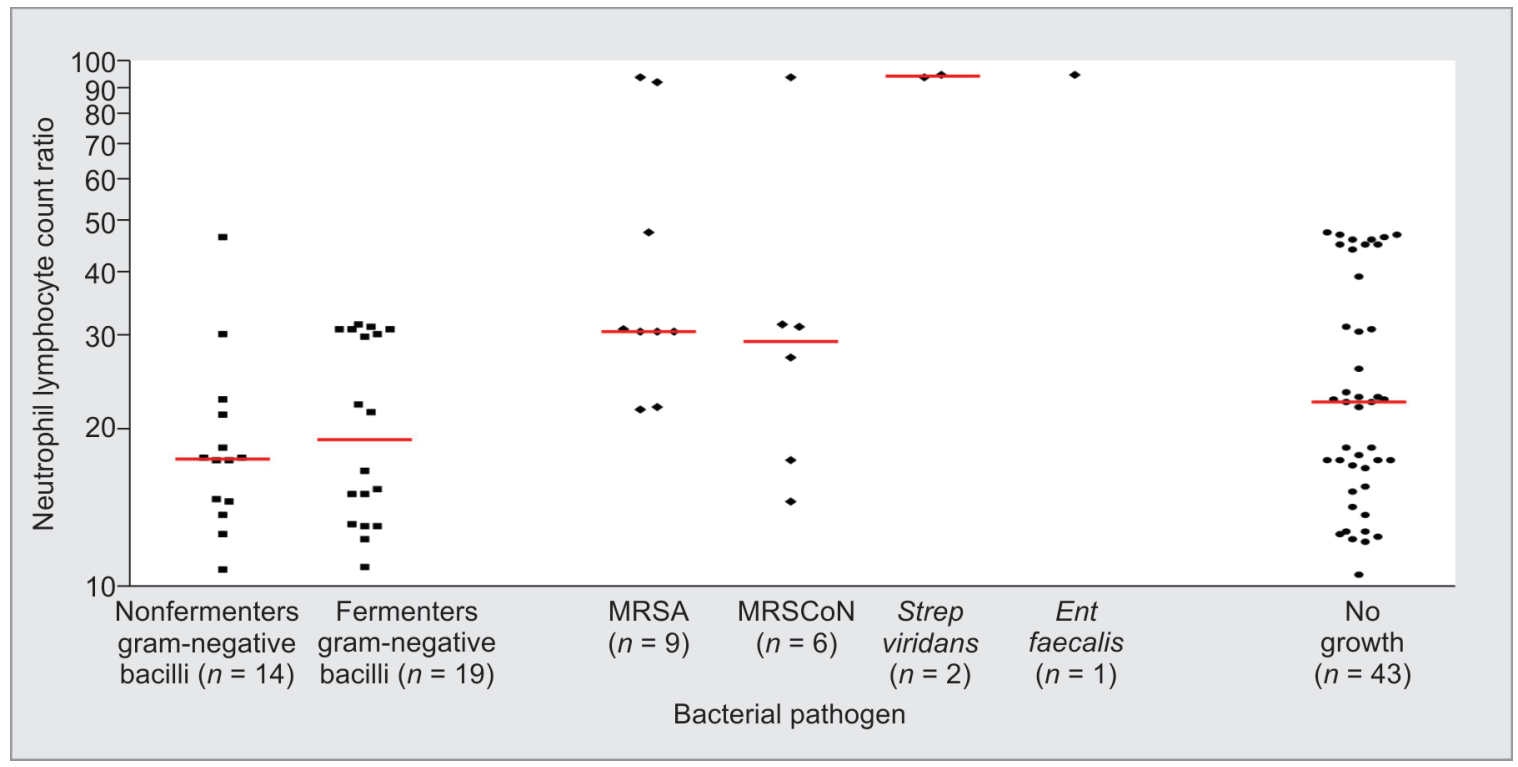

Fig. 1: Scattered-dot of NLCR to pathogenic bacteria in blood culture results. 
Is NLCR a Better Indicator of Sepsis with Gram-positive Bacterial Infection?

Table 1: Subject characteristics based on NLCR and blood culture results

\begin{tabular}{|c|c|c|c|c|c|}
\hline \multirow[b]{2}{*}{ Variables } & \multirow[b]{2}{*}{$n$} & \multicolumn{3}{|c|}{ NLCR in blood culture results } & \multirow[b]{2}{*}{$p$-value } \\
\hline & & Gram-negative & Gram-positive & No bacterial growth & \\
\hline \multicolumn{6}{|l|}{ Age } \\
\hline <65 year (median, IQR) & 67 & $17.6(10.9-93.0)$ & $31.3(22.0-96.0)$ & $20.4(10.6-47.5)$ & 0.001 \\
\hline$\geq 65$ year (median, IQR) & 27 & $21.8(12.4-32.0)$ & $32.0(14.7-96.0)$ & $31.0(12.4-48.0)$ & 0.239 \\
\hline \multicolumn{6}{|l|}{ Gender } \\
\hline Male (median, IQR) & 49 & $26.4(12.4-93.0)$ & $31.33(17.6-95.0)$ & $20.7(10.63-47.5)$ & 0.100 \\
\hline Female (median, IQR) & 45 & $17.6(10.9-31.3)$ & $31.7(14.7-96.0)$ & $23.0(12.3-48.0)$ & 0.005 \\
\hline \multicolumn{6}{|l|}{ Comorbidity } \\
\hline $\begin{array}{l}\text { Diabetes mellitus } \\
\text { (Median, IQR) }\end{array}$ & 19 & $14.7(10.9-31.7)$ & $48.0(14.7-95.0)$ & $18.0(12.3-47.0)$ & 0.085 \\
\hline $\begin{array}{l}\text { Heart disease } \\
\text { (Median, IQR) }\end{array}$ & 25 & $17.6(12.4-31.7)$ & $60.3(17.6-96.0)$ & $23.1(12.3-47.5)$ & 0.167 \\
\hline $\begin{array}{l}\text { Acute kidney injury } \\
\text { (Median, IQR) }\end{array}$ & 32 & $15.2(10.9-47.0)$ & $31.0(14.7-48.0)$ & $23.5(12.9-46.50$ & 0.069 \\
\hline $\begin{array}{l}\text { Chronic kidney disease } \\
\text { (median, IQR) }\end{array}$ & 31 & $21.6(13.8-93.0)$ & $93(22.0-96.0)$ & $22.6(12.3-47.5)$ & 0.020 \\
\hline $\begin{array}{l}\text { COPD } \\
\text { (median, IQR) }\end{array}$ & 11 & $30.7(30.3-31.3)$ & $48(31.0-93.0)$ & $22.8(17.6-46.5)$ & 0.071 \\
\hline $\begin{array}{l}\text { Geriatric } \\
\text { (median, IQR) }\end{array}$ & 32 & $21.8(12.4-47.0)$ & $31.5(14.7-96.0)$ & $23.0(12.4-47.5)$ & 0.320 \\
\hline \multicolumn{6}{|l|}{ Source of infection } \\
\hline $\begin{array}{l}\text { Respiratory tract } \\
\text { (median, IQR) }\end{array}$ & 66 & $18.7(10.9-93.0)$ & $31.3(14.7-96.0)$ & $20.4(10.6-48.0)$ & 0.011 \\
\hline $\begin{array}{l}\text { Intra-abdominal } \\
\text { (median, IQR) }\end{array}$ & 23 & $15.2(11.0-93.0)$ & $56.3(17.6-95.0)$ & $20.8(10.6-45.5)$ & 0.341 \\
\hline $\begin{array}{l}\text { Genitourinary tract } \\
\text { (median, IQR) }\end{array}$ & 10 & $26.0(15.2-32.0)$ & $23.3(4.7-32.0)$ & $35.3(23.0-47.5)$ & 0.572 \\
\hline $\begin{array}{l}\text { Skin and connective tissue } \\
\text { (median, IQR) }\end{array}$ & 20 & $16.4(10.9-23.0)$ & $95.0(14.7-96.0)$ & $18.6(10.6-47.5)$ & 0.089 \\
\hline
\end{tabular}

Table 2: Leukocyte count, absolute neutrophil count, absolute lymphocyte count, and NLCR based on blood culture results: Gram-negative, gram-positive, and no bacterial growth

\begin{tabular}{|c|c|c|c|c|}
\hline \multirow[b]{2}{*}{ Variable } & \multicolumn{3}{|c|}{ Blood culture results $(N=94)$} & \multirow[b]{2}{*}{$p$-value } \\
\hline & Gram-negative $(n=33)$ & Gram-positive $(n=18)$ & No bacterial growth $(n=43)$ & \\
\hline $\begin{array}{l}\text { Leukocyte/mm³ } \\
\text { Median (IQR) }\end{array}$ & $\begin{array}{l}15,620 \\
(11,425-22,835)\end{array}$ & $\begin{array}{l}21,375 \\
(12,410-26,098)\end{array}$ & $\begin{array}{l}15,070 \\
(10,850-22,500)\end{array}$ & 0.279 \\
\hline $\begin{array}{l}\text { Abs. Neutrophil/mm } \mathrm{mm}^{3} \\
\text { Median (IQR) }\end{array}$ & $\begin{array}{l}13,746 \\
(10,102-20,394)\end{array}$ & $\begin{array}{l}19,380 \\
(11,409-24,080)\end{array}$ & $\begin{array}{l}14,003 \\
(9,223-20,847)\end{array}$ & 0.254 \\
\hline $\begin{array}{l}\text { Abs. Lymphocyte } / \mathrm{mm}^{3} \\
\text { Median (IQR) }\end{array}$ & $\begin{array}{c}712 \\
(573-1,138)\end{array}$ & $\begin{array}{c}360 \\
(239-742)\end{array}$ & $\begin{array}{c}593 \\
(342-967)\end{array}$ & 0.007 \\
\hline $\begin{array}{l}\text { NLCR\% } \\
\text { Median (IQR) }\end{array}$ & $\begin{array}{c}17.8 \\
(14.3-30.7) \\
\end{array}$ & $\begin{array}{c}31.5 \\
(26.3-95.0) \\
\end{array}$ & $\begin{array}{c}22.8 \\
(15.67-22.75) \\
\end{array}$ & 0.001 \\
\hline
\end{tabular}

Continuous variables were presented as median (IQR). $p$ value was obtained using the Kruskal-Wallis test. NLCR: Neutrophil-lymphocyte count ratio Bold font indicates with $p$ value $<0.05$

the subjects, except in patients with CKD. In this group, the NLCR value is higher in gram-positive blood culture than in gramnegative. A study conducted by Yuan et al. showed that NLCR was associated with the risk of end-stage renal disease (ESRD) or stage 4 CKD. ${ }^{9}$ NLCR can be used in risk assessment for ESRD among patients with advanced CKD. ${ }^{2}$ In other words, NLCR is an indicator of inflammation in CKD, especially among those with more advanced stages. Classical risk factors, such as DM and low-GFR, were more powerful predictors of progression. ${ }^{10}$

Our study showed that there were significant differences in NLCR in patients with respiratory tract infection. A similar result was found by Nugraha et al., which stated that respiratory tract infections were the highest source of infection. ${ }^{11}$ Stepko et al. found that pneumonia (respiratory tract infection) was the most 
Table 3: Leukocyte count, absolute neutrophil count, absolute lymphocyte count, and NLCR based on blood culture results: gram-negative and gram-positive

\begin{tabular}{lccc}
\hline & \multicolumn{2}{c}{ Blood culture results $(\mathrm{N}=51)$} & \\
\cline { 2 - 3 } Variable & $\begin{array}{l}\text { Gram-negative } \\
n=33\end{array}$ & $\begin{array}{l}\text { Gram-positive } \\
n=18\end{array}$ & -value \\
\hline $\begin{array}{l}\text { NLCR } \\
\text { Median (IQR) }\end{array}$ & $17.8(14.3-30.7)$ & $31.5(26.3-95.0)$ & $<0.001$ \\
$\begin{array}{l}\text { Leukocyte } \\
\text { Median (IQR) }\end{array}$ & $15,620(11,425-22,835)$ & $21,375(12,410-26,098)$ & 0.315 \\
$\begin{array}{l}\text { Abs. neutrophil } \\
\text { Median (IQR) }\end{array}$ & $13,746(10,102-20,394)$ & $19,380(11,409-24,080)$ & 0.229 \\
$\begin{array}{l}\text { Abs. lymphocyte } \\
\text { Median (IQR) }\end{array}$ & $712(573-1,138)$ & $360(239-742)$ & 0.002 \\
\hline Con
\end{tabular}

Continuous variables were presented as median (IQR). $p$ value was obtained using the MannWhitney test. NLCR: Neutrophil-lymphocyte count ratio

Bold font indicates with $p$ value $<0.05$

Table 4: Leukocyte count, absolute neutrophil count, absolute lymphocyte count, and NLCR based on gram-negative nonfermenter and fermenter groups

\begin{tabular}{|c|c|c|c|}
\hline \multirow[b]{2}{*}{ Variable } & \multicolumn{2}{|c|}{ Gram-negative } & \multirow[b]{2}{*}{$p$-value } \\
\hline & Nonfermenters $=14$ & Fermenters $=19$ & \\
\hline \multicolumn{4}{|l|}{ NLCR } \\
\hline Median (IQR) & $17.7(14.5-21.9)$ & $21.8(13.3-31.3)$ & 0.455 \\
\hline \multicolumn{4}{|l|}{ Leukocyte } \\
\hline Median (IQR) & $13,670(11,433-18,210)$ & $17,180(11,400-28,790)$ & 0.255 \\
\hline \multicolumn{4}{|c|}{ Abs. neutrophil } \\
\hline Median (IQR) & $12,144(10,115-15,571)$ & $15,462(9,256-25,047)$ & 0.215 \\
\hline \multicolumn{4}{|c|}{ Abs. lymphocyte } \\
\hline Median (IQR) & $813(573-1,051)$ & $687(531-1,201)$ & 0.771 \\
\hline
\end{tabular}

common cause of sepsis in individuals aged over $65 .^{12}$ The simple calculation of the neutrophil-lymphocyte ratio (NLR) that we found correlating stronger with serum c-reactive protein (CRP) than total white blood cells could be of help when assessing patients with community-acquired pneumonia, with mean NLR of $10.2 \pm 8.8 .^{13}$ Overall, the NLCR (Mean \pm SD) was increased in patients with community-acquired pneumonia even more when patients were admitted to the hospital $(14.4 \pm 12.4)$ or ICU $(18.7 \pm 19.9)$ or died in hospital $(23.3 \pm 16.8)^{14}$

Based on a study by De Jager et al., the number of leukocytes of $4.0 \times 10^{9} / \mathrm{L}$ or $12.0 \times 10^{9} / \mathrm{L}$ was used as the definition of systemic inflammatory syndrome response. ${ }^{15}$ This is due to the phenomenon that neutrophilia often occurred during an inflammatory reaction.

The NLCR in patients with gram-positive bacteria was significantly higher compared to gram-negative bacteria because exotoxin in gram-positive bacteria can trigger an inflammatory reaction. Vidas BRAHMS study has shown that NLCR values indicate the severity of infection during the normal condition, NLR value of $4.19 \pm 4.36(\%)$, local infection NLR value of $5.68 \pm 8.99(\%)$, systemic infection (sepsis) NLR value of $11.78 \pm 11.04(\%)$, and severe sepsis NLR value of $16.87 \pm 9.55(\%) .{ }^{16}$ Gram-positive bacterial structure has peptidoglycan layers approximately 50 times thicker than those of gram-negative bacteria, and the peptidoglycan strands are also more tightly cross-linked. Furthermore, teichoic and lipoteichoic acids are unique to gram-positive bacteria. ${ }^{17}$
Gram-positive bacteria induced much more interleukin (IL-12) than did gram-negative bacteria and also induced stronger major histocompatibility complex class II-restricted IFN- $\gamma$ production in unfractionated blood mononuclear cells than did gram-negative species, so that the inflammatory reaction is more severe, which can be seen by NLCR value. ${ }^{17}$

On the contrary, gram-negative does not trigger more recruitment of neutrophil because gram-negative has less thick wall with glycoprotein or lipopolysaccharide that can be quickly attacked by a neutrophil. Virulence of gram-negative bacteria depends on its glycoprotein that can cause dysregulation of the immune system in sepsis. ${ }^{18}$

Regarding sepsis's etiology, a higher number of NLCR are associated with disease severity and dismal outcome. In the study conducted by George et al., 78.4\% of sepsis patients with NLCR score $>5$ were associated with more than two organ dysfunctions. ${ }^{19}$ Rehman et al., in their study, stated that NLCR is comparable with other sepsis biomarkers (CRP, procalcitonin, and sequential organ failure assessment score) as a marker of disease severity. ${ }^{20}$ Hence, a higher NLCR score can be used to initiate robust empirical therapy in patients with sepsis.

The limitation of this study is that it has a small sample size and was not checked for interleukins or other inflammatory markers; so, it needs further research for the interleukin as markers to monitor patients with sepsis. 


\section{Conclusion}

NLCR can differentiate bacterial pathogen infection by gramnegative and gram-positive. Therefore, NLCR can help clinicians in initiating the appropriate empirical antibiotic therapy for the patient with sepsis. However, a larger study is needed to confirm its real effectiveness as a guide in initiating empirical antibiotic therapy.

\section{Author Contributions}

Uun Sumardi contributed to the conception and design of the work, data analysis, interpretation and writing up, and final approval of the version to be published.

Diah Retno Prihardianti contributed to the conception or design of the work, revising the work, analysis, interpretation, and writing up.

Primal Sudjana contributed to the conception or design of the work, and revising the work

\section{Highlights}

NLCR can differentiate bacterial pathogen infection by gramnegative and gram-positive. It can also predict possible pathogenic bacteria as a cause of sepsis.

\section{OrCID}

Uun Sumardi ๑ https://orcid.org/0000-0003-2211-1636

Diah R Prihardianti @ https://orcid.org/0000-0002-9668-4413

Primal Sudjana 이 https://orcid.org/0000-0001-7772-702X

\section{References}

1. Phua J, Ngerng W, See K, Tay C, Kiong T, Lim H, et al. Characteristics and outcomes of culture-negative versus culture-positive severe sepsis. Crit Care 2013;17(5):R202. DOI: 10.1186/cc12896.

2. Rudd KE, Johnson SC, Agesa KM, Shackelford KA, Tsoi D, Kievlan DR, et al. Global, regional, and national sepsis incidence and mortality, 1990-2017: analysis for the Global Burden of Disease Study. Lancet (London, England) 2020:395(10219):200-211. DOI: 10.1016/S01406736(19)32989-7.

3. Parwati I. Pola Mikroba dan kepekaan terhadap berbagai antimikroba Rumah Sakit Umum Pusat DR. Hasan Sadikin Bandung. Divisi mikrobiologi klinik Instalasi Laboratori-um Klinik RSHS; 2017. p. 96-98.

4. Dellinger RP, Levy MM, Rhodes A, Annane D, Gerlach H, Opal $S M$, et al. Surviving sepsis campaign: international guidelines for management of severe sepsis and septic shock: 2012. Crit Care Med 2013;41(2):580-637. DOI: 10.1097/CCM.0b013e31827e83af.

5. Singer M, Deutschman CS, Seymour CW, Shankar-Hari M, Annane D, Bauer $\mathrm{M}$, et al. The third international consensus definitions for sepsis and septic shock (Sepsis-3). JAMA 2016;315(8):801-810. DOI: 10.1001/ jama.2016.0287.

6. Jonathan PE, Zulfariansyah A. Correlation between neutrophillymphocyte count ratio and procalcitonin in sepsis and septic shock. MKB 2019;51(3):165-171. DOI: 10.15395/mkb.v51n3.1642.
7. Nurdani A, Hadi U, Arfijanto MV, Rusli M, Bramantono, Miftahussurur M. Neutrophil-lymphocyte ratio and procalcitonin levels in sepsis patients. New Armenian Med J 2019;13(1):48-54. http://repository. unair.ac.id/id/eprint/91873

8. Yana K. Faktor-faktor yang mempengaruhi rendahnya positivitas hasil kultur darah pada penderita sepsis. Rumah Sakit Dr. Hasan Sadikin Universitas Padjajaran; 2017.

9. Yuan Q, Wang J, Peng Z, Zhou Q, Xiao X, Xie Y, et al. Neutrophil-tolymphocyte ratio and incident end-stage renal disease in Chinese patients with chronic kidney disease: results from the Chinese Cohort Study of Chronic Kidney Disease (C-STRIDE). J TransI Med 2019;17(1):86. DOI: 10.1186/s12967-019-1808-4.

10. Altunoren O, Akkus G, Sezal DT, Ciftcioglu M, Guzel FB, Isiktas S, et al. Does neutrophil to lymphocyte ratio really predict Chronic Kidney Disease progression? Int Urol Nephrol 2019;51(1):129-137. DOI: 10.1007/s11255-018-1994-7.

11. Nugraha HP, Sudjana P. Gambaran karakteristik pasien sepsis dengan nilai KHM dari terapi empiris antibiotika golongan sefalosporin di instalasi rawat inap Rumah Sakit Dr. Hasan Sadikin Universitas Padjajaran 2016 (Bandung).

12. Stepko B, Coundary. What causes this surprisingly large health threat and how to prevent it - in and out of the hospital. American Association of Retired Persons; 2018.

13. Pantzaris ND, Platanaki C, Pierrako C, Karamouzos V, Velissaris D. Neutrophil-to-lymphocyte ratio relation to sepsis severity scores and inflammatory biomarkers in patients with communityacquired pneumonia: a case series. J Transl Int Med 2018;6(1):43-46. DOI: 10.2478/jtim-2018-0009.

14. De Jager CPC, Wever PC, Gemen EFA, Kusters R, van GageldonkLafeber AB, van der Poll T, et al. The neutrophil-lymphocyte count ratio in patients with community-acquired pneumonia. PLoS One 2012;7(10):e46561. DOI: 10.1371/journal.pone.0046561.

15. De Jager CP, Van Wijk PT, Mathoera RB, de Jongh-Leuvenink J, van der Poll T, Wever PC. Lymphocytopenia and neutrophil lymphocyte count ratio predict bacteremia better than conventional infection markers in an emergency care unit. Crit Care 2010;14(5):R192. DOI: 10.1186/cc9309.

16. Gürol G, Çiftci ï, Terizi HA, Atasoy AR, Ozbek A, Köroğlu M. Are there standardized cut-off values for neutrophil-lymphocyte ratios in bacteremia or sepsis? J Microbiol Biotechnol 2015;25(4):521-525. DOI: 10.4014/jmb.1408.08060.

17. Hessle C, Andersson B, Wold AE. Gram-positive bacteria are potent inducers of monocytic interleukin-12 (IL-12) while Gram-negative bacteria preferentially stimulate IL-10 production. Infect Immun 2000;68(6):3581-3586. DOI: 10.1128/IAI.68.6.3581-3586.2000.

18. Feldman C, Alanee S, Yu VL, Richards GA, Ortqvist A, Rello J, et al. Severity of illness scoring systems in patients with bacteraemic pneumococcal pneumonia: implications for the Intensive Care Unit Clin Microbiol Infect 2009;15(9):850-857. DOI: 10.1111/j.14690691.2009.02901.x.

19. George AA, Thomas TP, Gaffoor A. The role of neutrophil/lymphocyte ratio in predicting the severity of sepsis in a tertiary care hospital in South India: a retrospective study. Int J Res Med Sci 2020;8(5). DOI: 10.18203/2320-6012.ijrms20201490.

20. Rehman FU, Khan A, Aziz A, Iqbal M, Mahmood SBZ, Ali N. Neutrophils to lymphocyte ratio: earliest and efficacious markers of sepsis. Cureus 2020;12(10):e10851. DOI: 10.7759/cureus.10851. 